\title{
Impact of the ESM-1 Gene Expression on Outcomes in Stage II/III Gastric Cancer Patients Who Received Adjuvant S-1 Chemotherapy
}

\author{
KAZUKI KANO ${ }^{1}$, KENTARO SAKAMAKI ${ }^{2}$, NAOHIDE OUE ${ }^{3}$, YAYOI KIMURA ${ }^{4}$, \\ ITARU HASHIMOTO ${ }^{5}$, KENTARO HARA $^{1,5}$, YUKIO MAEZAWA $^{5,6}$, TORU AOYAMA ${ }^{5}$, \\ HIROHITO FUJIKAWA ${ }^{1}$, YUKIHIKO HIROSHIMA ${ }^{1}$, TAKANOBU YAMADA ${ }^{1}$, HIROSHI TAMAGAWA ${ }^{5}$,

 \\ NORIO YUKAWA ${ }^{5}$, TAKAKI YOSHIKAWA ${ }^{8}$, SOICHIRO MORINAGA $^{1}$, YASUSHI RINO ${ }^{5}$, \\ WATARU YASUI ${ }^{3}$, MUNETAKA MASUDA $^{5}$, YOHEI MIYAGI $^{9}$ and TAKASHI OSHIMA ${ }^{1}$ \\ ${ }^{1}$ Department of Gastrointestinal Surgery, Kanagawa Cancer Center, Yokohama, Japan; \\ ${ }^{2}$ Department of Biostatistics and Informatics, Graduate School of Medicine, \\ The University of Tokyo, Tokyo, Japan; \\ ${ }^{3}$ Department of Molecular Pathology, Hiroshima University Institute \\ of Biomedical and Health Science, Hiroshima, Japan; \\ ${ }^{4}$ Advanced Medical Research Center, Yokohama City University, Yokohama, Japan; \\ ${ }^{5}$ Department of Surgery, Yokohama City University, Yokohama, Japan; \\ ${ }^{6}$ Department of Surgery, Tokyo Metropolitan Cancer and Infectious \\ Disease Center Komagome Hospital, Tokyo, Japan; \\ ${ }^{7}$ Department of Respiratory Surgery, Kanagawa Cancer Center, Yokohama, Japan; \\ ${ }^{8}$ Department of Gastric Surgery, National Cancer Center Hospital, Tokyo, Japan; \\ ${ }^{9}$ Kanagawa Cancer Center Research Institute, Yokohama, Japan
}

\begin{abstract}
Background/Aim: Endothelial cell-specific molecule-1 (ESM-1) is a soluble proteoglycan which has important role in various biological events. We investigated the impact of the ESM-1 expression in cancer tissues on outcomes in stage II/III gastric cancer patients who received adjuvant S-1 chemotherapy. Patients and Methods: The ESM-1 mRNA expression in cancerous tissues and adjacent normal mucosa from 253 patients was measured. The associations between the ESM-1 gene expression and the survival and clinicopathological features were investigated. Results: A significant association was observed between high ESM-1 expression and undifferentiated adenocarcinoma. The
\end{abstract}

This article is freely accessible online.

Correspondence to: Takashi Oshima, Department of Gastrointestinal Surgery, Kanagawa Cancer Center, Yokohama, Kanagawa, 2418515, Japan. Tel: +81 455202222, Fax: +81 455202202, e-mail: oshimat@kcch.jp

Key Words: Gastric cancer, endothelial cell-specific molecule-1, ESM-1, adjuvant chemotherapy, S-1. overall survival curve was significantly lower in patients with high ESM-1 expression than in those with low expression ( $p=0.005)$. High ESM-1 expression was a significant independent prognosticator $(H R=2.291$, $p=0.007)$. Conclusion: ESM-1 gene expression in cancerous tissues is an important prognosticator in stage II/III gastric cancer patients who received adjuvant $S-1$ chemotherapy.

Gastric cancer is the fifth most major cancer among new cases and the third most common cause of cancer-associated mortality worldwide, numbering 1,033,701 and 781,631 in 2018, respectively (1). The Adjuvant Chemotherapy Trial of S1 for Gastric Cancer (ACTS-GC) demonstrated that adjuvant S-1 chemotherapy significantly improved the survival of patients who received D2 gastrectomy for pathological stage (pStage) II/III gastric cancer $(2,3)$. Furthermore, in the CLASSIC trial and JACCRO-07 trial, the effectiveness of capecitabine plus oxaliplatin therapy for pStage II/III gastric cancer and S-1 plus docetaxel therapy for pStage III was confirmed (4-6). Thus, fluoropyrimidine remains the key drug for adjuvant chemotherapy in gastric cancer patients (7).

Endothelial cell-specific molecule-1 (ESM-1) was originally cloned from a human endothelial cell cDNA 
Table I. The PCR primer sequences of ESM-1 and $\beta$-actin.

\begin{tabular}{ll}
\hline Primer & Sequence \\
\hline$E S M-1$ & \\
Sense primer & 5'-AAGGCTGCTGATGTAGTTC-3' \\
Antisense primer & 5'-GCTATTTATGGAAGTGTATGTGTTT-3' \\
$\beta$-actin & 5'-AGTCAGCCGCAT CTTCTT-3' \\
Sense primer & 5'-GCCCAATACGACCAAATCC-3' \\
Antisense primer & \\
\hline
\end{tabular}

library in 1996 (8). ESM1 is a soluble dermatan proteoglycan that can circulate in the bloodstream (9). The structure of ESM-1 is composed of a mature polypeptide of 165 amino acids, of which approximately $30 \mathrm{kDa}$ corresponds to a single dermatan sulfate chain (8). Recently, several authors have shown that ESM-1 is overexpressed at the mRNA and protein levels in various cancers (10-15). It was reported that the overexpression of ESM-1 plays an important role in development, angiogenesis, tumor growth, and so on (16). Furthermore, previous studies have reported that ESM-1 overexpression in tumor tissue was related to poor outcomes in patients with various malignancies (17-20). However, there is no available information concerning the correlation between the ESM-1 expression and long-term outcome in gastric cancer patients who receive adjuvant $\mathrm{S}-1$ chemotherapy.

Thus, we examined the impact of ESM-1 mRNA expression in cancer tissues regarding outcomes in patients treated with adjuvant S-1 chemotherapy for pStage II/III gastric cancer.

\section{Patients and Methods}

Patients and samples. We retrospectively analyzed the clinical data from 146 consecutive patients who underwent curative resection followed by adjuvant S-1 chemotherapy for the treatment of pStage II/III gastric cancer at Kanagawa Cancer Center and Yokohama City University between 2002 and 2010. As a comparison group, we concurrently studied the ESM-1 expression and long-term outcome in 107 patients who did not receive adjuvant chemotherapy with S-1.

Each tissue sample was engrafted in optimum cutting temperature compound (Sakura Finetechnical Co., Ltd., Tokyo, Japan) and instantly stored at $-80{ }^{\circ} \mathrm{C}$. We stained tissue specimens with eosin and hematoxylin and examined histopathologically. Sections were consisted of $>80 \%$ tumor cells and were used to extract RNA.

RNA extraction and complementary DNA (cDNA) synthesis. Total RNA was isolated from cancerous tissue and adjacent normal mucosa and was prepared with the use of Trizol (Gibco, Life Tech, Gaithersburg, MD, USA). Complementary DNA (cDNA) was synthesized from total RNA with an iScript cDNA synthesis kit (Bio-Rad Laboratories, Inc., Hercules, CA, USA).

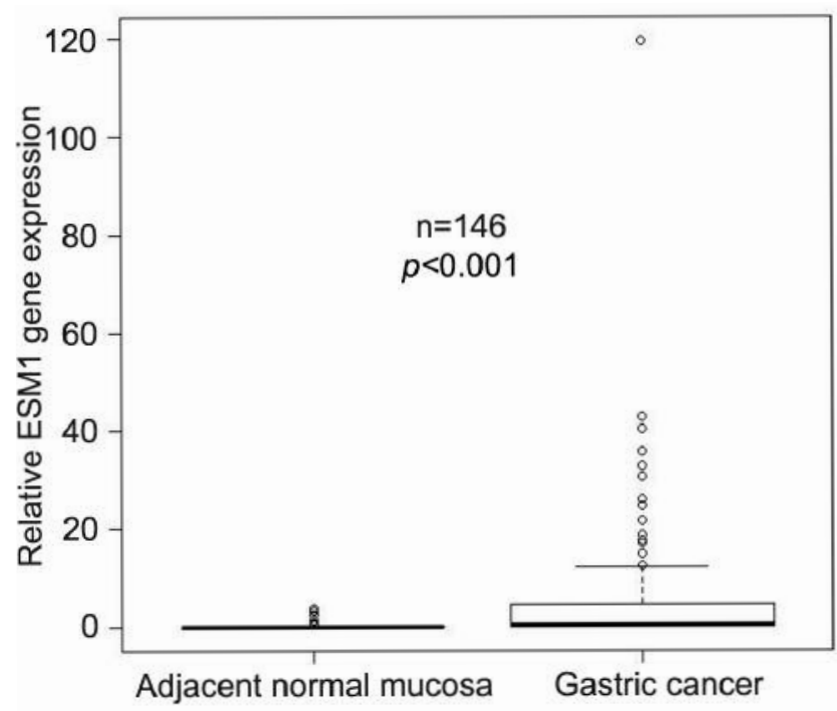

Figure 1. Comparison of ESM-1 gene expression between gastric cancerous tissues and adjacent normal mucosa.

Quantitative reverse transcription polymerase chain reaction ( $q R T$ $P C R)$. qRT-PCR was performed with iQ SYBR Green Supermix (Bio-Rad Laboratories). PCR reactions were performed in a total volume of $15 \mu \mathrm{l}$, which included $0.2 \mu \mathrm{g}$ of cDNA, $0.4 \mu \mathrm{M}$ of each primer, $7.5 \mu \mathrm{l}$ of iQ SYBR Green Supermix containing dATP, dCTP, dGTP and dTTP at concentrations of $400 \mu \mathrm{M}$ each, and 50 units $/ \mathrm{ml}$ of iTag DNA polymerase. After the PCR consisted of 3 min at $95{ }^{\circ} \mathrm{C}$, the cycling conditions were as follows: 40 cycles of denaturation of the cDNA at $95^{\circ} \mathrm{C}$ for $10 \mathrm{~s}$, annealing for $10 \mathrm{~s}$ at $60{ }^{\circ} \mathrm{C}$ for ESM-1 and $\beta$-actin, and a primer extension at $72{ }^{\circ} \mathrm{C}$ for $20 \mathrm{~s}$, finally hold on $72{ }^{\circ} \mathrm{C}$ for $10 \mathrm{~min}$. To evaluate the specific mRNA expression in samples, a standard curve was produced for each run, measuring three points of the human control cDNA (Clontech Laboratories, Inc., CA, USA). The concentration of each sample was calculated by relating its crossing point to a standard curve. The PCR primer sequences of ESM-1 and $\beta$-actin, as an internal control, are shown in Table I.

Statistical analyses. Gene expression levels were compared between gastric cancer and adjacent normal mucosa by the Wilcoxon's test. The expression of ESM-1 mRNA was categorized as low or high based on a cut-off value calculated using the maximum chi-square test $\left(\chi^{2}\right)$. The optimal cut-off point was selected by the minimum $p$ value method, whereas the internal validity of the cut-off point was evaluated with a two-fold cross-validation approach (21). The relationship between the ESM-1 mRNA expression and clinicopathological factors were evaluated with the $\chi^{2}$ test. The survival curves were calculated using the Kaplan-Meier method and compared by the log-rank test. The Cox proportional hazards model was used for the univariate and multivariate survival analyses to determine the risk factors. $p$-Values $<0.05$ were considered to indicate statistical significance. All statistical analyses were performed using the EZR (Saitama Medical Center, Jichi Medical University, Saitama, Japan), which is a graphical user interface for the R software program (The R Foundation for Statistical Computing, Vienna, Austria) (22). 
Table II. Comparison of the clinicopathological factors between high and low ESM1 expression.

\begin{tabular}{|c|c|c|c|c|}
\hline \multirow[t]{2}{*}{ Factors } & \multirow{2}{*}{$\begin{array}{l}\text { All patients } \\
\qquad(\mathrm{n}=146)\end{array}$} & \multicolumn{2}{|c|}{ ESM1 expression } & \multirow[t]{2}{*}{$p$-Value } \\
\hline & & Low $(n=63)$ & High $(n=83)$ & \\
\hline Age (years), Mean \pm SD & $65.8 \pm 9.4$ & $65.2 \pm 10.6$ & $66.3 \pm 8.4$ & 0.473 \\
\hline Gender & & & & 0.721 \\
\hline Male & $100(68.5 \%)$ & $42(66.7 \%)$ & $58(69.9 \%)$ & \\
\hline Female & $46(31.5 \%)$ & $21(33.3 \%)$ & $25(30.1 \%)$ & \\
\hline Tumor size (mm) & & & & 0.182 \\
\hline$<65$ & $69(47.3 \%)$ & $34(54.0 \%)$ & $48(57.8 \%)$ & \\
\hline$\geq 65$ & $77(52.7 \%)$ & $29(46.0 \%)$ & $35(42.2 \%)$ & \\
\hline Histological type & & & & 0.016 \\
\hline Differentiated & $90(61.6 \%)$ & $46(73.0 \%)$ & $44(53.0 \%)$ & \\
\hline Undifferentiated & $56(38.4 \%)$ & $17(27.0 \%)$ & $39(47.0 \%)$ & \\
\hline Pathological serosal invasion & & & & 0.736 \\
\hline Absent & $58(39.7 \%)$ & $24(38.1 \%)$ & $34(41.0 \%)$ & \\
\hline Present & $88(60.3 \%)$ & $39(61.9 \%)$ & $49(59.0 \%)$ & \\
\hline Pathological lymph-node metastasis & & & & 0.910 \\
\hline Absent & $19(13.0 \%)$ & $8(12.7 \%)$ & $11(13.3 \%)$ & \\
\hline Present & $127(87.0 \%)$ & $55(87.3 \%)$ & $72(86.7 \%)$ & \\
\hline Lymphatic invasion & & & & 0.430 \\
\hline Absent & $34(23.3 \%)$ & $17(27.0 \%)$ & $17(20.5 \%)$ & \\
\hline Present & $112(76.7 \%)$ & $46(73.0 \%)$ & $66(79.5 \%)$ & \\
\hline Venous invasion & & & 0.438 & \\
\hline Absent & $36(24.7 \%)$ & $18(28.6 \%)$ & $18(21.7 \%)$ & \\
\hline Present & $110(75.3 \%)$ & $45(71.4 \%)$ & $65(78.3 \%)$ & \\
\hline TNM pathological stage & & & 0.854 & \\
\hline II & $42(28.8 \%)$ & $19(30.2 \%)$ & $23(27.7 \%)$ & \\
\hline III & $104(71.2 \%)$ & $44(69.8 \%)$ & $60(72.3 \%)$ & \\
\hline
\end{tabular}

UICC, Union for International Cancer Control; ASA-PS, American Society of Anesthesiologists Physical Status; SD, standard deviation. Bold value shows significance.

Ethics. The present study was conducted in compliance with the 'ethical guidelines for clinical research' and with the Helsinki Declaration of 1975 , as revised in 1983. This study was approved by the Institutional Review Board (IRB) of Yokohama City University (approval number: 18-7A-4) and Kanagawa Cancer Center (approval number: epidemiological study-29). Written informed consent for using clinical data without identifying personal information was obtained from all patients the initiation of the study.

\section{Results}

ESM-1 mRNA expression. The results revealed that the ESM1 mRNA expression was significantly higher in cancer tissue [1.062 (0.000-15.349)] than in normal gastric mucosa $[0.426$ $(0.000-119.618)](p<0.001)$ (Figure 1).

Patient characteristics. Using the optimal cut-off point of the expression of the ESM-I mRNA, patients were classified into those with low expression of ESM-1 mRNA and high expression of ESM-1 mRNA. The patients' demographic and clinical characteristics are summarized in Table II. Tumors with an undifferentiated type had a significantly higher ESM-1 expression than those with a differentiated type $(p=0.016)$.

Survival analysis. Patients with a high expression of ESM-1 mRNA have a significantly worse OS than those with a low expression ( $p=0.005$; Figure 2 ). The 5-year OS rate was $57.5 \%$ in the patients with a high expression of ESM-1 mRNA and $77.8 \%$ in those with a low expression of ESM-1 mRNA. The OS curve in the reference group of pStage II/III gastric cancer patients who did not receive adjuvant $\mathrm{S}-1$ chemotherapy are shown in Figure 3. There was no significant difference in the survival between the patients with a high expression of ESM1 mRNA and those with a low expression $(p=0.141)$.

The clinicopathological factors were analyzed to determine their prognostic significance for OS (Table III). The univariate analyses demonstrated that the TNM stage and ESM-1 mRNA expression were significant prognostic factors for OS. The lymph node metastasis was marginally significant prognostic factor. The multivariate analyses demonstrated that the TNM stage and ESM-1 mRNA expression were significant independent prognostic factors for OS. 


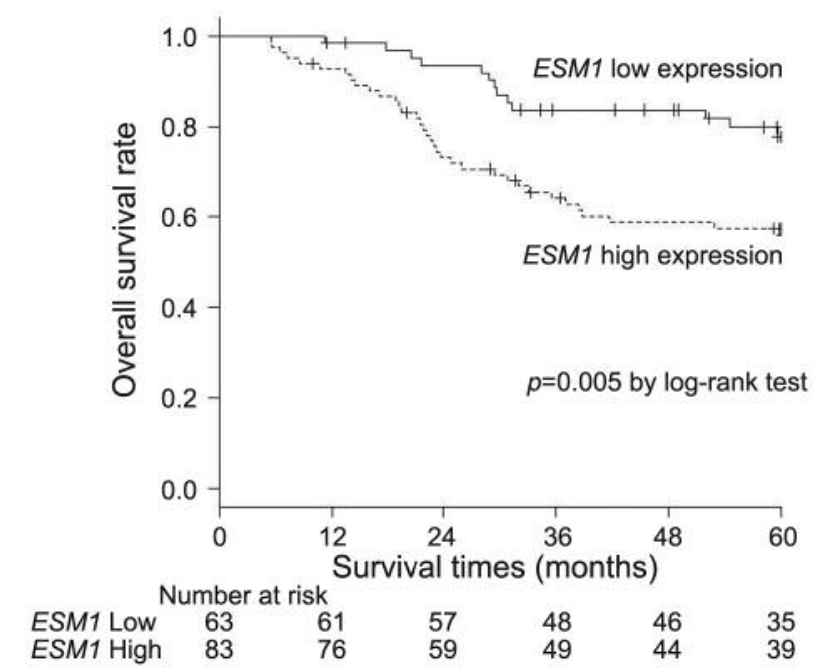

Figure 2. Comparison of overall survival between high and low ESM-1 gene expression in pathological stage II/III gastric cancer patients who received curative gastrectomy followed by adjuvant $S-1$ chemotherapy.

\section{Discussion}

The present study evaluated the impact of the ESM- 1 mRNA expression on long-term outcome in pStage II/III gastric cancer patients who received curative resection followed by adjuvant S-1 chemotherapy. The major finding of this study was that the patients with high expression of ESM-1 mRNA had significantly worse survival than those with low expression of ESM-1 mRNA. Our results suggested that the $E S M-1$ gene expression in cancerous tissue is an important prognosticator in these patients.

We first examined the expression of ESM-1 mRNA in cancerous tissues and adjacent normal mucosa. Several previous studies have compared the relative mRNA expression of the $E S M-1$ gene between various types of cancer tissue and adjacent normal mucosa $(10,20,23)$. It was reported that the ESM-1 expression was higher in gastric cancer tissue than in non-cancerous tissue in 159 samples (20). Our results are consistent with those previous findings, as the expression of $E S M-1$ mRNA was significantly higher in the gastric cancer tissue than in the paired adjacent normal mucosa.

We, next, examined the relationship between the ESM-1 mRNA expression and the clinicopathological factors in gastric cancer. Liu et al. reported that the overexpression of ESM-1 mRNA was significantly correlated with distant metastasis, vascular invasion, and Borrmann type IV after radical resection for gastric cancer (20). Furthermore, they reported that the local expression of ESM-1 was correlated with vascularity and tumor aggressiveness (20). In the present study, tumors with an undifferentiated type had a high ESM-1 expression.



Figure 3. Comparison of overall survival between high and low ESM-1 gene expression in pathological stage II/III gastric cancer patients who received curative gastrectomy, but did not receive adjuvant $S-1$ chemotherapy.

We then assessed the relationship between ESM-1 gene expression and long-term outcome in pStage II/III gastric cancer patients who received curative resection followed by adjuvant S-1 chemotherapy. Previous studies reported that a high ESM-1 mRNA expression was associated with a poor outcome in patients with various cancers, including gastric cancer (17-20). In the present study, a high ESM-1 mRNA expression was associated with significantly poorer outcomes than a low expression in locally advanced gastric cancer patients who received adjuvant chemotherapy with S1. Furthermore, a multivariate analysis revealed that a high expression of ESM-1 mRNA was an independent risk factor for poor outcomes. In contrast, in the patients who did not receive adjuvant $\mathrm{S}-1$ chemotherapy, the overall survival did not significantly differ between the patients with a high expression of ESM-1 mRNA and those with a low expression of ESM-1 mRNA. These results suggest that a high expression of $E S M-1$ mRNA in gastric cancer tissue indicates a high risk of recurrence in pStage II/III gastric cancer patients who received curative resection followed by adjuvant S-1 chemotherapy. Although further studies are necessary, such patients may be better treated with only close follow-up at an outpatient or with the combination of S-1 plus other anticancer agents.

The mechanism underlying the association of a high expression of ESM-1 mRNA in cancerous tissue with a poor prognosis in pStage II/III gastric cancer patients who received curative resection followed by adjuvant S-1 chemotherapy is poorly understood at present. However, previous reports have hypothesized several mechanisms: 
Table III. Uni- and multivariate Cox proportional hazards analyses of clinicopathological factors for the overall survival.

\begin{tabular}{|c|c|c|c|c|c|c|c|}
\hline \multirow[t]{2}{*}{ Factors } & \multirow{2}{*}{$\begin{array}{l}\text { Number of } \\
\text { patients }(\%)\end{array}$} & \multicolumn{3}{|c|}{ Univariate } & \multicolumn{3}{|c|}{ Multivariate } \\
\hline & & HR & $95 \% \mathrm{CI}$ & $p$-Value & HR & $95 \% \mathrm{CI}$ & $p$-Value \\
\hline Age (years) & & & & 0.320 & & & \\
\hline$<65$ & $58(50.4 \%)$ & 1.000 & & & & & \\
\hline$\geq 65$ & $57(49.6 \%)$ & 0.758 & $0.439-1.309$ & & & & \\
\hline Gender & & & & 0.826 & & & \\
\hline Female & $23(20.0 \%)$ & 1.000 & & & & & \\
\hline Male & $93(80.0 \%)$ & 1.069 & $0.593-1.927$ & & & & \\
\hline Tumor size (mm) & & & & 0.124 & & & \\
\hline$<65$ & $49(42.6 \%)$ & 1.000 & & & & & \\
\hline$\geq 65$ & $66(57.4 \%)$ & 1.551 & $0.887-2.712$ & & & & \\
\hline Histological type & & & & 0.980 & & & \\
\hline Differentiated & $17(14.8 \%)$ & 1.000 & & & & & \\
\hline Undifferentiated & $98(85.2 \%)$ & 0.993 & $0.564-1.748$ & & & & \\
\hline Pathological serosal invasion & & & & 0.219 & & & \\
\hline Absent & $93(80.9 \%)$ & 1.000 & & & & & \\
\hline Present & $22(19.1 \%)$ & 1.438 & $0.805-2.569$ & & & & \\
\hline Pathological lymph-node metastasis & & & & 0.073 & & & 0.769 \\
\hline Absent & $59(51.3 \%)$ & 1.000 & & & 1.000 & & \\
\hline Present & $56(48.7 \%)$ & 2.906 & $0.906-9.327$ & & 1.220 & $0.324-4.594$ & \\
\hline TNM pathological stage & & & & 0.002 & & & 0.007 \\
\hline II & $58(50.4 \%)$ & 1.000 & & & 1.000 & & \\
\hline III & $57(49.6 \%)$ & 3.825 & $1.632-8.965$ & & 3.788 & $1.436-9.993$ & \\
\hline Lymphatic invasion & & & & 0.357 & & & \\
\hline Absent & $51(44.3 \%)$ & 1.000 & & & & & \\
\hline Present & $64(55.7 \%)$ & 1.383 & $0.694-2.758$ & & & & \\
\hline Venous invasion & & & & 0.476 & & & \\
\hline Absent & $39(33.9 \%)$ & 1.000 & & & & & \\
\hline Present & $76(66.1 \%)$ & 1.274 & $0.654-2.482$ & & & & \\
\hline ESM1 expression & & & & 0.006 & & & 0.007 \\
\hline Low & $75(65.2 \%)$ & 1.000 & & & 1.000 & & \\
\hline High & $40(34.8 \%)$ & 2.319 & $1.270-4.233$ & & 2.291 & $1.250-4.20$ & \\
\hline
\end{tabular}

HR, Hazard ratio; CI, confidence interval; UICC, Union for International Cancer Control. Bold values show significance.

ESM-1 is expressed in the tumor endothelium and is upregulated by angiogenic growth factors, such as vascular endothelial growth factor (VEGF) (24). The expression of ESM-1 is also correlated with the balance of positive $\mathrm{PKC} / \mathrm{NFKB}$ and negative PI3K/AKT/FKHRL1 signaling pathways (25). In addition, it has been recently shown that hypoxia-inducible factor-1a (HIF-1a) was regulated by ESM-1 (26). HIF-1a expression reduced apoptosis in cancer cells through modulation of the expression of apoptotic proteins, such as Bcl-2, Bid, leading to drug resistance against chemotherapeutic agents like 5fluorouracil $(27,28)$.

Caution is required when interpreting the current results, since the present study has several potential limitations. First, this study examined the ESM-1 mRNA expression in cancerous tissues. It will be necessary to examine both the mRNA expression and protein expression using the same specimen to determine the clinical utility of a protein as a biomarker. Second, there is the issue of heterogeneity in cancerous tissue. The sample from which the mRNA was extracted was $5 \mathrm{~mm} \times 5 \mathrm{~mm} \times 10 \mu \mathrm{m}$ (for 3 sheets) of cancer tissue. Although that tissue included the deepest part of the tumor, they did not accurately represent the entire tumor.

From the results of this study, it would be suggested to administrate the appropriate regimen based on the ESM-1 mRNA expression level for pStage II/III gastric cancer in clinical practice. For example, a more efficient adjuvant chemotherapy, such as S-1 plus docetaxel (6), should be administrated if the ESM-1 mRNA expression level is high in gastric cancer tissue samples after surgery in patients with pStage II/III gastric cancer. On the other hand, no adjuvant chemotherapy and careful monitoring may administrate if the ESM-1 mRNA expression level is low in patients with stage II gastric cancer who have organ dysfunction, such as in elderly patients. However, validations and prospective studies in are necessary. 
In conclusion, a high expression of ESM-1 mRNA in cancer tissue is an important prognosticator in stage II/III gastric cancer patients who received adjuvant S-1 chemotherapy.

\section{Conflicts of Interest}

The Authors have no conflicts of interest to declare regarding this study.

\section{Authors' Contributions}

KK and TO contributed to the conception and design of the study. KK, YK, IH, KH, YM, TA, HF, TY, TO, HC, TY, YM, and TO contributed to the data collection and assembly. All of the authors contributed to the data acquisition and interpretation of the analyzed data. KK wrote the manuscript. All of the Authors contributed to the critical revision of the paper. All of the Authors read and approved the final manuscript.

\section{Acknowledgements}

The Authors thank Kazue Yoshihara for her technical support.

\section{References}

1 Bray F, Ferlay J, Soerjomataram I, Siegel RL, Torre LA and Jemal A: Global cancer statistics 2018: GLOBOCAN estimates of incidence and mortality worldwide for 36 cancers in 185 countries. CA Cancer J Clin 68(6): 394-424, 2018. PMID: 30207593. DOI: $10.3322 /$ caac. 21492

2 Sakuramoto S, Sasako M, Yamaguchi T, Kinoshita T, Fujii M, Nashimoto A, Furukawa H, Nakajima T, Ohashi Y, Imamura H, Higashino M, Yamamura Y, Kurita A, Arai K and ACTS-GC Group: Adjuvant chemotherapy for gastric cancer with S-1, an oral fluoropyrimidine. N Engl J Med 357(18): 1810-1820, 2007. PMID: 17978289. DOI: 10.1056/NEJMoa072252

3 Sasako M, Sakuramoto S, Katai H, Kinoshita T, Furukawa H, Yamaguchi T, Nashimoto A, Fujii M, Nakajima T and Ohashi Y: Five-year outcomes of a randomized phase III trial comparing adjuvant chemotherapy with S-1 versus surgery alone in stage II or III gastric cancer. J Clin Oncol 29(33): 4387-4393, 2011. PMID: 22010012. DOI: 10.1200/JCO.2011.36.5908

4 Bang YJ, Kim YW, Yang HK, Chung HC, Park YK, Lee KH, Lee KW, Kim YH, Noh SI, Cho JY, Mok YJ, Kim YH, Ji J, Yeh TS, Button P, Sirzén F, Noh SH and CLASSIC trial investigators: Adjuvant capecitabine and oxaliplatin for gastric cancer after D2 gastrectomy (CLASSIC): a phase 3 open-label, randomised controlled trial. Lancet 379(9813): 315-321, 2012. PMID: 22226517. DOI: 10.1016/S0140-6736(11)61873-4

5 Noh SH, Park SR, Yang HK, Chung HC, Chung IJ, Kim SW, Kim HH, Choi JH, Kim HK, Yu W, Lee JI, Shin DB, Ji J, Chen JS, Lim Y, Ha S, Bang YJ and CLASSIC trial Investigators: Adjuvant capecitabine plus oxaliplatin for gastric cancer after D2 gastrectomy (CLASSIC): 5-year follow-up of an open-label, randomised phase 3 trial. Lancet Oncol 15(12): 1389-1396, 2014. PMID: 25439693. DOI: 10.1016/S1470-2045(14)70473-5

6 Kodera Y, Yoshida K, Kochi M, Ichikawa W, Kakeji Y, Sano T, Nagao N, Takahashi M, Takagane A, Nakamura M, Kaji M, Okitsu H, Nomura T, Matsui T, Yoshikawa T, Matsuyama J, Yamada M, Ito Y, Takeuchi M and Fujii M: A randomized phase III study comparing S-1 plus docetaxel with S-1 alone as a postoperative adjuvant chemotherapy for curatively resected stage III gastric cancer (JACCRO GC-07 trial). J Clin Oncol 36(15 Suppl): 4007, 2018. DOI: 10.1200/JCO.2018.36.15_suppl.4007

7 Moon JH, Fujiwara Y, Hirao M, Imamura H, Kimura Y, Fujitani K, Fujita J, Tamura S, Takiguchi S, Yano M, Mori M and Doki Y: Randomized controlled trial of adjuvant chemotherapy with fluoropyrimidines versus surgery-alone for gastric cancer. Anticancer Res 37(6): 3061-3067, 2017. PMID: 28551645. DOI: 10.21873/anticanres.11661

8 Lassalle P, Molet S, Janin A, Heyden JV, Tavernier J, Fiers W, Devos R and Tonnel AB: ESM-1 is a novel human endothelial cell-specific molecule expressed in lung and regulated by cytokines. J Biol Chem 271(34): 20458-20464, 1996. PMID: 8702785. DOI: $10.1074 / j b c .271 .34 .20458$

9 Sarrazin S, Adam E, Lyon M, Depontieu F, Motte V, Landolfi C, Lortat-Jacob H, Bechard D, Lassalle P and Delehedde M: Endocan or endothelial cell specific molecule-1 (ESM-1): a potential novel endothelial cell marker and a new target for cancer therapy. Biochim Biophys Acta 1765(1): 25-37, 2006. PMID: 16168566. DOI: 10.1016/j.bbcan.2005.08.004

10 Lenburg ME, Liou LS, Gerry NP, Frampton GM, Cohen HT and Christman MF: Previously unidentified changes in renal cell carcinoma gene expression identified by parametric analysis of microarray data. BMC Cancer 3: 31, 2003. PMID: 14641932. DOI: $10.1186 / 1471-2407-3-31$

11 van 't Veer LJ, Dai H, van de Vijver MJ, He YD, Hart AA, Bernards $\mathrm{R}$ and Friend $\mathrm{SH}$ : Expression profiling predicts outcome in breast cancer. Breast Cancer Res 5(1): 57-58, 2002. PMID: 12559048 . DOI: $10.1186 /$ bcr562

12 Borczuk AC, Shah L, Pearson GD, Walter KL, Wang L, Austin $\mathrm{JH}$, Friedman RA and Powell CA: Molecular signatures in biopsy specimens of lung cancer. Am J Respir Crit Care Med 170(2): 167-174, 2004. PMID: 15087295. DOI: 10.1164/rccm. 200401-066OC

13 Seftor EA, Meltzer PS, Schatteman GC, Gruman LM, Hess AR, Kirschmann DA, Seftor RE and Hendrix MJ: Expression of multiple molecular phenotypes by aggressive melanoma tumor cells: role in vasculogenic mimicry. Crit Rev Oncol Hematol 44(1): 17-27, 2002. PMID: 12398997.

14 Alberts SR, Cervantes A and van de Velde CJ: Gastric cancer: epidemiology, pathology and treatment. Ann Oncol 14(Suppl 2): 31-36, 2003. PMID: 12810455. DOI: 10.1093/annonc/mdg726

15 Steiner N, Hajek R, Sevcikova S, Borjan B, Untergasser G, Göbel $\mathrm{G}$ and Gunsilius E: The plasma levels of the angiogenic cytokine endocan are elevated in patients with multiple myeloma. Anticancer Res 38(9): 5087-5092, 2018. PMID: 30194153. DOI: 10.21873 /anticanres.12828

16 Nishida N, Yano H, Nishida T, Kamura T and Kojiro M: Angiogenesis in cancer. Vasc. Health Risk Manag 2(3): 213, 2006. PMID: 17326328. DOI: 10.2147/vhrm.2006.2.3.213

17 Parkin DM, Bray F, Ferlay $\mathrm{J}$ and Pisani P: Global cancer statistics, 2002. CA Cancer J Clin 55(2): 74-108, 2005. PMID: 15761078. DOI: 10.3322/canjclin.55.2.74

18 Leroy X, Aubert S, Zini L, Franquet H, Kervoaze G, Villers A, Delehedde M, Copin MC and Lassalle P: Vascular endocan (ESM-1) is markedly overexpressed in clear cell renal cell carcinoma). Histopathology 56(2): 180-187, 2010. PMID: 20102396. DOI: $10.1111 / \mathrm{j} .1365-2559.2009 .03458 . x$ 
19 Perey L, Benhattar J, Peters R, Jaunin P and Leyvraz S: High tumour contamination of leukaphereses in patients with small cell carcinoma of the lung: a comparison of immunocytochemistry and RT-PCR. Br J Cancer 85(11): 17131721, 2001. PMID: 11742493. DOI: 10.1054/bjoc.2001.2177

20 Liu N, Zhang LH, Du H, Hu Y, Zhang GG, Wang XH, Li JY and Ji JF: Overexpression of endothelial cell specific molecule-1 (ESM-1) in gastric cancer. Ann Surg Oncol 17(10): 2628-2639, 2010. PMID: 20383661. DOI: 10.1245/s10434-010-1037-9

21 Mazumdar M, Smith A and Bacik J: Methods for categorizing a prognostic variable in a multivariable setting. Stat Med 22(4): 559-571, 2003. PMID: 12590414. DOI: 10.1002/sim.1333

22 Kanda Y: Investigation of the freely available easy-to-use software "EZR" (Easy R) for medical statistics. Bone Marrow Transplant 48(3): 452-458, 2013. PMID: 23208313. DOI: $10.1038 / \mathrm{bmt} .2012 .244$

23 Zuo L, Zhang SM, Hu RL, Zhu HQ, Zhou Q, Gui SY, Wu Q and Wang Y: Correlation between expression and differentiation of endocan in colorectal cancer. World J Gastroenterol 14(28): 4562-4568, 2008. PMID: 18680240. DOI: 10.3748/wjg.14.4562

24 Delehedde M, Devenyns L, Maurage CA and Vivès RR: Endocan in cancers: A lesson from a circulating dermatan sulfate proteoglycan. Int J Cell Biol 2013: 705027, 2013. PMID: 23606845. DOI: 10.1155/2013/705027

25 Abid MR, Yi X, Yano K, Shih SC and Aird WC: Vascular endocan is preferentially expressed in tumor endothelium. Microvasc Res 72(3): 136-145, 2006. PMID: 16956626. DOI: 10.1016/j.mvr.2006.05.010
26 Kim JH, Park MY, Kim CN, Kim KH, Kang HB, Kim KD and Kim JW: Expression of endothelial cell-specific molecule-1 regulated by hypoxia inducible factor- $1 \alpha$ in human colon carcinoma: impact of ESM-1 on prognosis and its correlation with clinicopathological features. Oncol Rep 28(5): 1701-1708, 2012. DOI: $10.3892 /$ or.2012.2012

27 Zhou J, Schmid T, Schnitzer S and Brüne B: Tumor hypoxia and cancer progression. Cancer Lett 237(1): 10-21, 2006. PMID: 16002209. DOI: 10.1016/j.canlet.2005.05.028

28 Liu JB, Jian T, Yue C, Chen D, Chen W, Bao TT, Liu HX, Cao Y, Li WB, Yang Z, Hoffman RM and Yu C: Chemo-resistant gastric cancer associated gene expression signature: Bioinformatics analysis based on gene expression omnibus. Anticancer Res 39(4): 1689-1698, 2019. PMID: 30952707. DOI: 10.21873/anticanres. 13274
Received October 19, 2019

Revised November 4, 2019

Accepted November 6, 2019 